Electrical, Electronics and communications, and Computer Engineering

\title{
Thixotropic Hardening of Fao Clay
}

\author{
Ahmed Shakir Kamil* \\ Researcher \\ College of Engineering-University of Baghdad \\ Email: ahmed21shakir@gmail.com
}

\author{
Ala Nasir Aljorany \\ Professor \\ College of Engineering-University of Baghdad \\ Email:alaljorany@gmail.com
}

\begin{abstract}

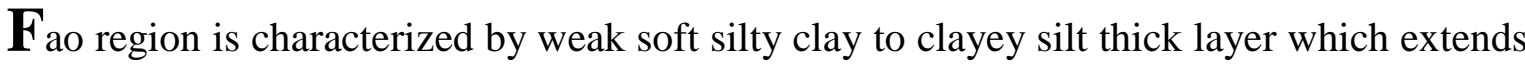
to a depth of about $20 \mathrm{~m}$. The construction of some structures on such soils may needs piles. During the installation of driven piles, the soil geotechnical properties are exposed to significant changes result due to shearing under large shear strains. These changes significantly decrease the shear strength of the virgin soil due to the destruction of soil structure caused by remolding. The degradation of shear strength is usually followed by strength regaining which is called "Thixotropy". In this study, the thixotropic effect on Fao clay was investigated. Many disturbed and undisturbed soil samples were brought from Fao region. Some of the soil samples were thoroughly remolded in the laboratory in its natural water content and molded as direct shear specimens. More than 180 specimens were prepared and tested over 36 weeks in order to accurately assess the percentage of strength regaining with time passing. The results show that soil remolding causes about a $45 \%$ reduction in shear strength in comparing with the shear strength of the intact soil. This reduced percent in shear strength was almost fully regained after 25 weeks due to thixotropic effect.
\end{abstract}

Keywords: Clay, Thixotropy, Strength regaining, Thixotropic effect, Remolding.

\section{استعادة التصلب بتربة الفاو}

\section{الخلاصة}

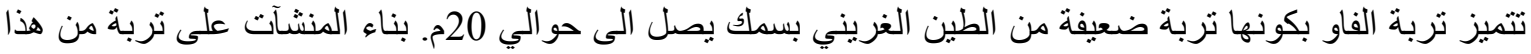

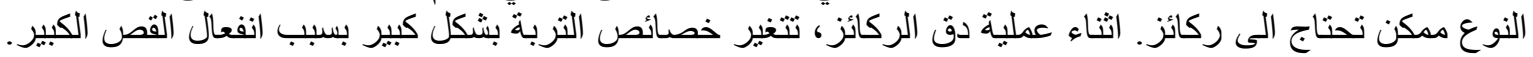

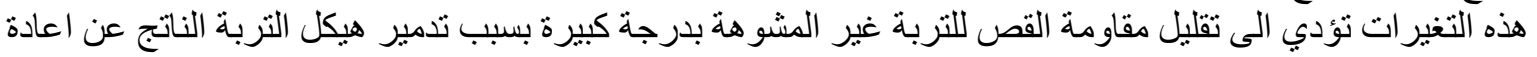

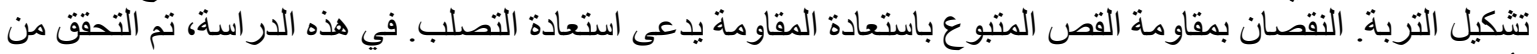

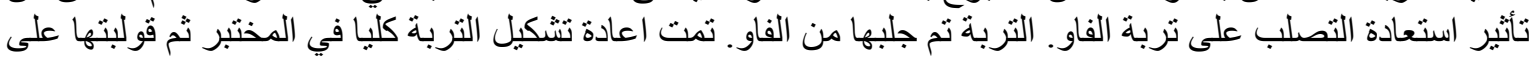

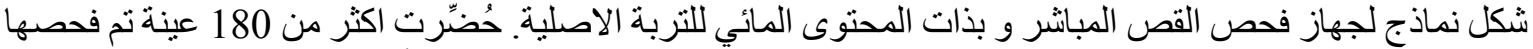

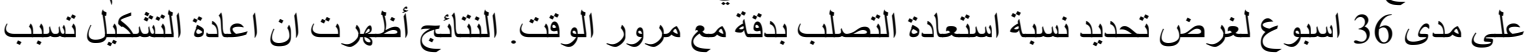

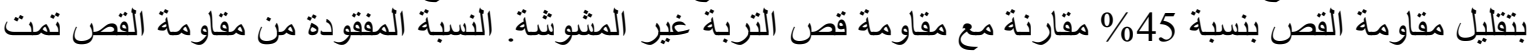

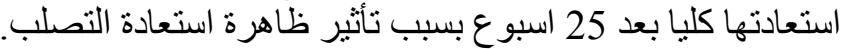
الكلمات الرئيسية: الطين، استعادة التصلب، استعادة القوة، تأثير استعادة التصلب، اعادة التبلئ التشكيل.

*Corresponding author

Peer review under the responsibility of University of Baghdad.

https://doi.org/10.31026/j.eng.2019.05.05

2520-3339 (C) 2019 University of Baghdad. Production and hosting by Journal of Engineering.

This is an open access article under the CC BY-NC license http://creativecommons.org/licenses/by-nc/4.0/). Article received: 1/5/2018

Article accepted: 6/6/2018 


\section{INTRUDUCTION}

Thixotropy is one of the oldest and commonly known rheological phenomena in colloidal science. This term "Thixotropy" was firstly presented by Petrify in 1927 . Then used by Fruedlinch, 1935, to pronounce the phenomenon of the revocable and isothermal solidliquid change of colloidal structures after mechanical excitation, Zahng, et al., 2017. Thixotropic behavior was detected in many geotechnical engineering fields and usually seen in landslide soils such as clayey rocks, Soloneko, 1977, and clayey soils, Khaldoun, et al., 2009.

Soil Remolding causes a significant loss in the initial soil strength due to the destruction of soil structure and interparticle forces. With time passing, the soil starts to regain its lost strength. This process of strength regaining without changing in volume, water content and/or effective stress is called Thixotropic phenomenon. This phenomenon, also known as "thixotropic hardening', occurs due to gradual rearrangement of soil particles to form new and stable soil structure. Soil particle rearrangement occurred due to the bonding forces caused by the increased mechanical stability and equilibrium, Skempton and Northey, 1952, Mitchell, 1960, Chan and Yong, 2014, and Zahng, et al., 2017.

Thixotropic hardening is really important, but a complex phenomenon. The thixotropic mechanism of soil results from Remolding remain unclear, Zhang, et al., 2017. Until now, there is no formula which evaluates the thixotropic effect for all types of soil. This may be due to the dependency of thixotropic effect on soil structure, mineral compensation of the soil, time and ionic concentration, Skempton and Northey, 1952, Mitchell, 1960, Farsakh, et al., 2015, and Shahriar, et al., 2018. The comparison between the results of the previous researchers showed ambiguous conclusions and the percentage of strength regaining different according to the type of soil, Zahng, et al., 2017. From series of tests, Mathes, 1968, observed that the maximum strength ratio (ratio of strength at time $(t)$ to the strength at time (0) (i.e. the soil strength immediately after Remolding) is 1.7 while, Zhang, et al., 2017, observed that the maximum strength ratio is 2.58 .

In this research, the thixotropic effect on Fao clay is investigated. Fao region which is located at the extreme southern part of Iraq is chosen as a study area. The importance of Fao region emerges from the fact that it is the unique marine front in Iraq. Many oil exporting facilities and other infrastructures are planned to be constructed in this region. This study is therefore devoted to evaluate and assess the thixotropic effects on the engineering behavior of Fao clay. This was performed through an extensive laboratory testing program.

\section{EXPERIMENTAL WORK}

The soft clayey soil in the Fao region extends to $20-30 \mathrm{~m}$ below the natural ground level (NGL). The ground surface is almost flat and the groundwater table is close to the (NGL). Many disturbed and undisturbed soil samples were brought from a depth of about $3 \mathrm{~m}$. As shown in Plate 1, an open pit was initially performed by an excavation machine to about 2 $m$ depth then by manual excavation for the last meter to avoid sample disturbance, as much as possible. Thin wall steel cylinders were then pushed by hand inside the soil. The wall thickness of each cylinder is $(0.2 \mathrm{~cm})$ with the dimensions of $(20 \mathrm{~cm})$ in diameter and $(25$ $\mathrm{cm}$ ) in height. After pushing the cylinders through the soil, the soil surrounding the cylinders were manually removed. Cylindrical block of soil samples with minimum disturbance were obtained and ready to be collected from the pit. The collected samples were then carefully sealed and transported to Baghdad. All the laboratory tests were carried out at the Laboratories of the Department of Civil Engineering / University of Baghdad. 


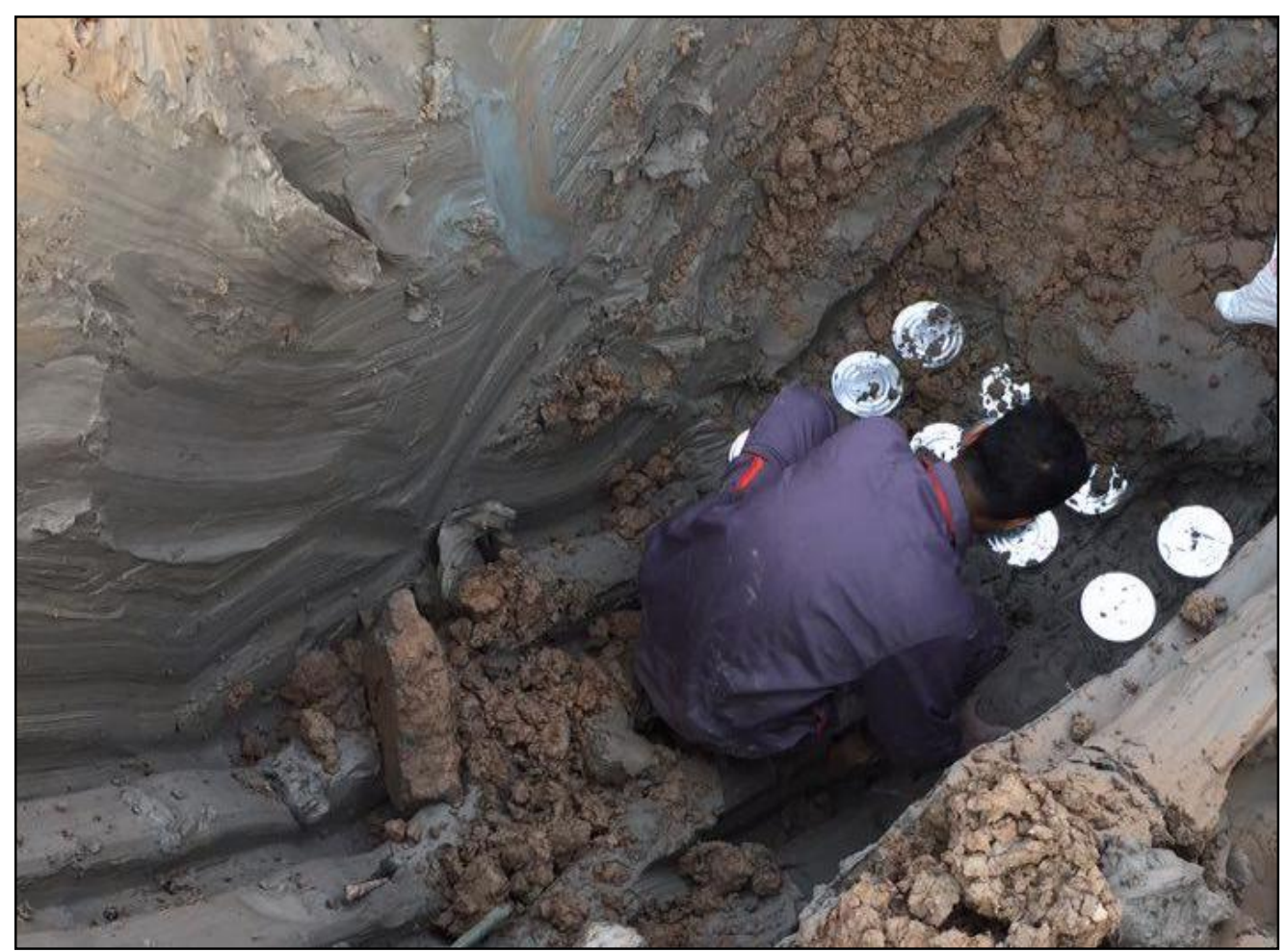

Plate 1. Collecting of undisturbed soil samples from about $3 \mathrm{~m}$ deep open bit.

\subsection{Geotechnical Properties of Fao Soil}

Table 1 displays the physical properties of the soil samples collected from Fao region. It can be noticed that the soil is silty clay with a natural water content of about $36 \%$ and about $100 \%$ saturation. The liquid limit is about 48 and the plasticity index is 21 . The specific gravity of the soil is about 2.75 . The obtained results are almost consistent with those available in the literature.

Table 1. Physical properties of the virgin soil.

\begin{tabular}{|c|c|c|c|}
\hline Type of test & $\begin{array}{c}\text { Results and Description of the } \\
\text { averaged value }\end{array}$ & $\begin{array}{l}\text { No. of } \\
\text { trails }\end{array}$ & $\begin{array}{r}\text { ASTM } \\
\text { designation }\end{array}$ \\
\hline Liquid limit & $48 \%$ & 3 & \multirow[b]{2}{*}{ D4318 } \\
\hline Plastic limit & $27 \%$ & 3 & \\
\hline Specific gravity, Gs & 2.756 & 3 & D854 \\
\hline Sieve Analysis & $99 \%$ passing sieve No. 200 & 3 & D6913 \\
\hline Hydrometer test & $\begin{array}{l}70 \% \text { is the percentage of clay, } \\
\text { while } 29 \% \text { is the percentage of silt, } \\
\text { and } 1 \% \text { is the percentage of sand. }\end{array}$ & 3 & D7928 \\
\hline Water content & $36 \%$ & 5 & D2216 \\
\hline Bulk Unite weight & $18.4 \mathrm{kN} / \mathrm{m}^{3}$ & 5 & D 7263 \\
\hline Void ratio & 0.99 & 6 & D2435 \\
\hline
\end{tabular}




\begin{tabular}{|c|c|c|c|}
\hline Porosity & 0.497 & - & $\begin{array}{c}\text { Physical } \\
\text { relationships }\end{array}$ \\
\hline Degree of saturation & $100 \%$ & - & \\
\hline
\end{tabular}

Table 2 shows the percentages of some of the chemical compounds that exist in the natural soil. It can be noticed that the percent of organic matters is about $4.2 \%$. The value of $\mathrm{pH}$ which is about 8.04 indicates a weak base nature of the soil.

For soft clayey soils, the most important geotechnical properties are the undrained shear strength and the compressibility. In this research, undrained shear strength is obtained by three different tests, namely; the direct shear test, the vane shear test, the unconfined compression test, and the undrained triaxial test. In practice, the condition of soil Remolding during pile driving is quite similar to that occurs in direct shear test since the shearing plane is already defined at the interface between pile and soil. An emphasis is, therefore, paid to the results of the direct shear test provided that the rate of shearing is quick enough to maintain the undrained condition. Bro, et al., 2013 indicated that when the test is so rapid that shearing time $\left(\mathrm{t}_{\mathrm{f}}\right)$ is less than $\left(\mathrm{t}_{50} / 8\right)$, the undrained condition for the clayey soil can be satisfied in the direct shear test, where $\mathrm{t}_{50}$ is the time to reach $50 \%$ consolidation.

Each geotechnical property was determined from at least 5 relevant tests. Table 3 displays the values of the undrained shear strength as obtained from different test apparatuses. The difference in the values of the undrained shear strength may be attributed to the differences in the size and the boundary conditions of each the tested samples.

Table 2. Chemical test results.

\begin{tabular}{|l|l|}
\hline Chemical Compound & Percentage $(\%)$ \\
\hline Total $\mathrm{SO}_{3}$ & 0.475 \\
\hline Total soluble salt (T.S.S) & 0.4 \\
\hline Organic content \% & 4.2 \\
\hline Total Cl\% & 3.8 \\
\hline pH value & 8.04 \\
\hline
\end{tabular}

The normal load that was applied in the direct shear test was $7.15 \mathrm{kPa}$ which is relatively small. This was mainly because of the consistency of the Fao clay. By experience, it was noted that higher normal applied load causes squeezing of soft clay out of the shear box, specifically from tiny space in the area of the contact surface between the two parts of the shear box. The soil squeezing occurred when increasing the normal load for about $25 \mathrm{kPa}$.

Table 3 shows also the value of the undrained shear strength of both undisturbed and remolded soil samples using various tests. From direct shear test results, the remolded shear strength is about $53 \%$ of that of the intact soil. Fig. 1 shows the relation between the shear stress and the shear displacement for a typical direct shear test on an undisturbed soil sample. 
Table 3. Shear strength values from different test.

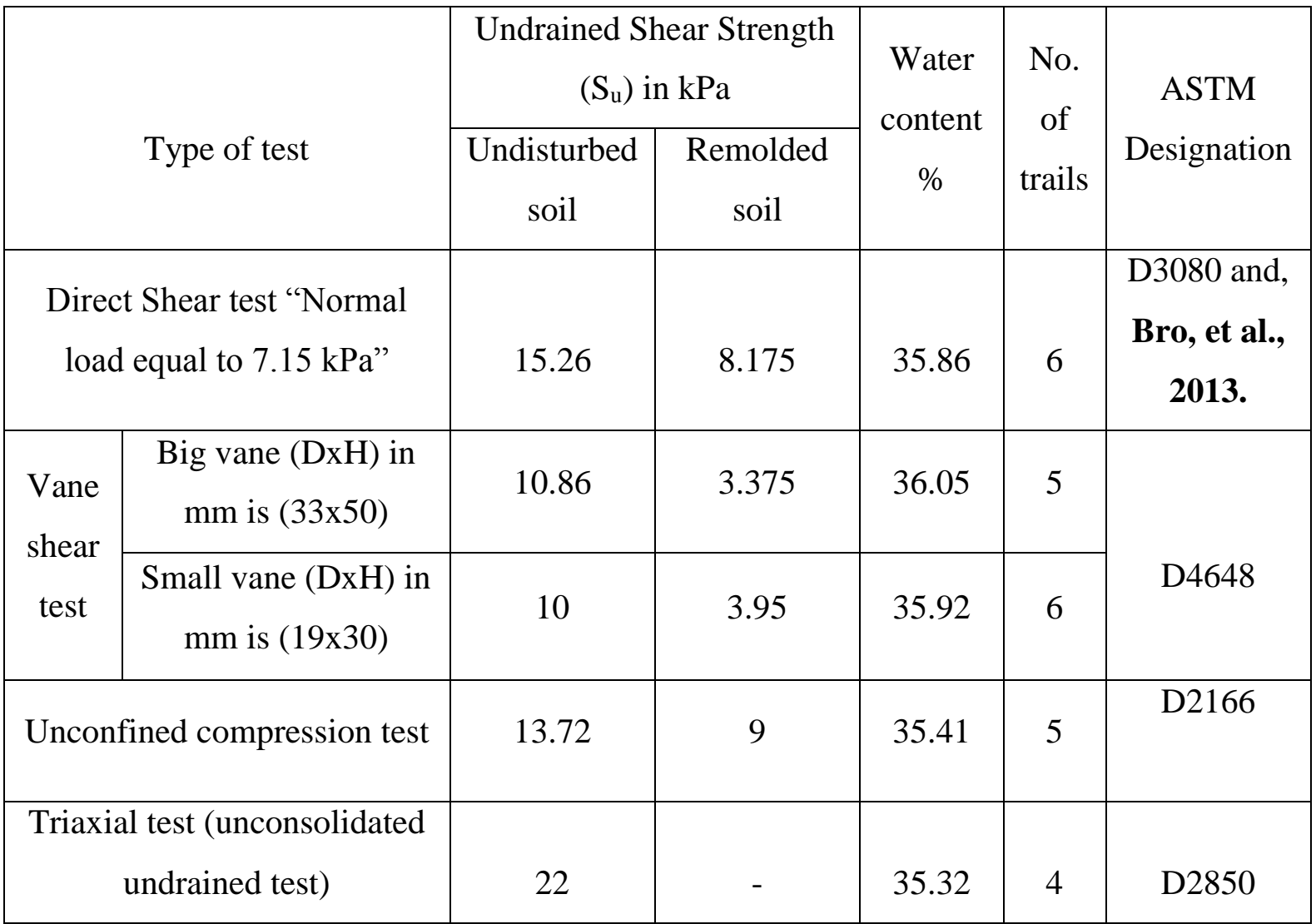

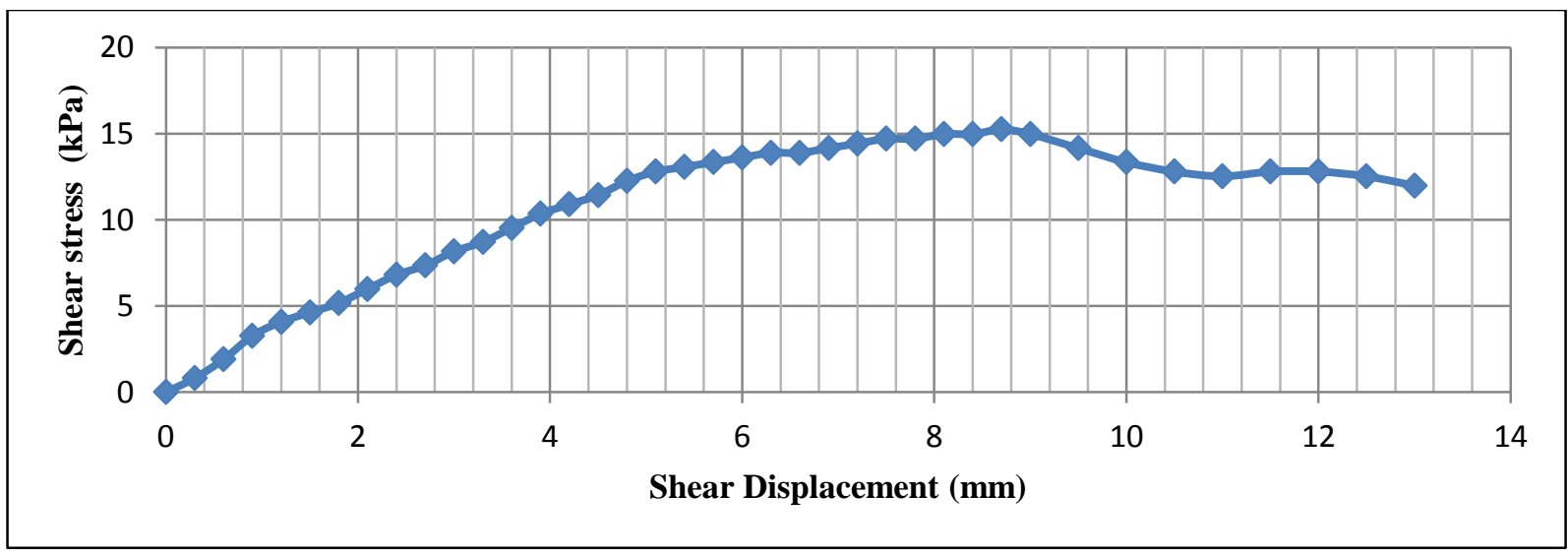

Figure 1. Shear displacement vs shear stress in the direct shear test for intact soil.

\subsection{Specimens Preparing for Thixotropic Effects}

In order to investigate the Thixotropic effects on the Fao clay, about 180 soil specimens are to be prepared in a special manner to be tested throughout a time frame of about 36 weeks. The following steps were performed to reconstitute the remolded soil specimens:

1. An amount of about $24 \mathrm{~kg}$ of the disturbed soil was brought from the Fao region. This disturbed soil was collected from the soil that surrounds the thin metallic cylinders and from the soil that manually collected from the same depth in which the undisturbed soil was collected. Then the disturbed samples were sealed by triple plastic bags and conveyed to the laboratory. 
2. The disturbed soil was spread and air dried then crushed into small pieces then pulverized before oven drying.

3. The amount of water which is needed to reach the in-situ water content was added gradually to the pulverized dry soil.

4. During adding the required amount of water, the process of kneading was done simultaneously to ensure homogeneous reconstituted soil which was almost fully remolded.

5. The prepared soil is then spread again and cut by a special cutting box that was designed to obtain soil samples that fit the direct shear mold with minimum disturbance.

6. As shown in Plate 2, about 180 specimens of the reconstituted soil were prepared then tightly sealed to maintain the natural water content and stored in a humid restricted place until the testing date.

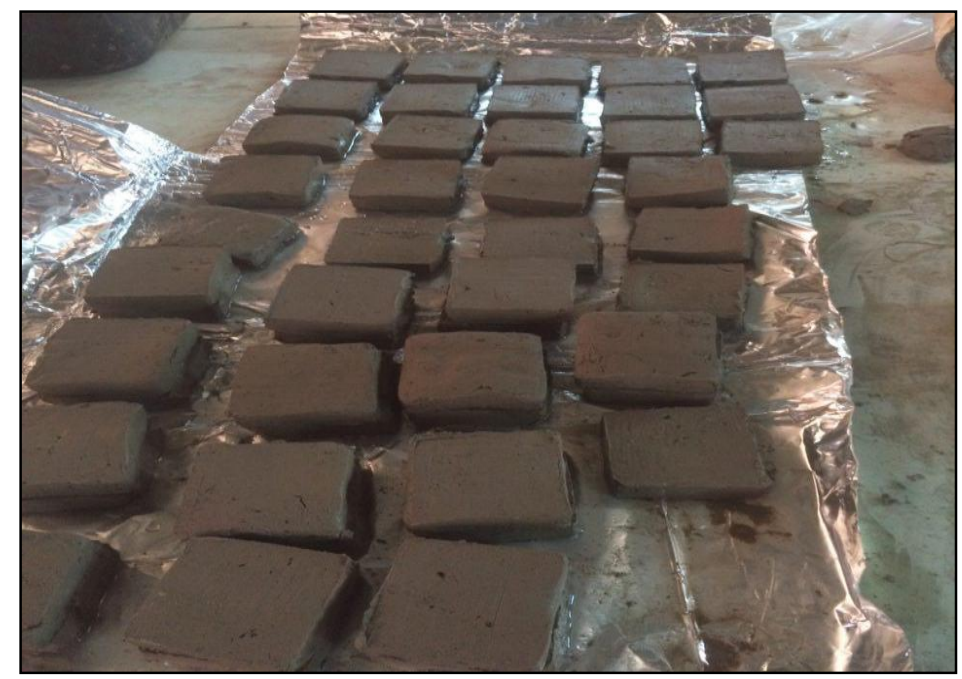

Plate 2. Reconstituted soil specimens prepared for Thixotropic effects investigation.

\subsection{Specimens Testing for Thixotropic Effects}

After keeping the prepared soil specimens away from any mechanical disturbance or water content losing the testing program started from day one after preparing and continued to about 36 weeks. During the first week, four tests were performed. At each specific testing time, three specimens were tested to have an idea about the consistency of the obtained results. As mentioned earlier, the direct shear test was used to evaluate the undrained shear strength of each specimen. Following the recommendation of Bro, et al., 2013, the shearing rate was controlled so that the ultimate strength was reached within a time period which was less that $t_{50} / 8$. For each of the tested specimen, the water content was checked again to ensure that all samples are almost of the same water content of the intact soil with an acceptable deviation of $(+2 \%$ to $-2 \%)$. This mainly because of the consistency of clayey soils is highly affected by its water content.

Table 4 reviews the obtained values of the undrained shear strength for each of the three specimens that were tested at each specific time. It can be noticed that the three obtained values are almost consistent.

\section{RESULTS ANALYSIS AND DISCUSSIONS}

In order to have a clear idea about the variation of the undrained shear strength with time, the following parameters are calculated and defined as: 
- $\quad \mathrm{SuD} \%$ : Percent of undrained shear strength degradation due to the remolding of soil compared to that of intact soil.

- SuR \%: Percent of strength regaining due to thixotropic effect compared to the lost amount of strength upon remolding.

These parameters are mathematically expressed as follows:

$\mathrm{SuD} \%=\frac{\text { Intact Soil Su-Su at week (i) }}{\text { Intact Soil Su }} \times 100$

$\mathrm{SuR} \%=\frac{\text { Intact Soil Su }- \text { Su at week (i) }}{\text { Intact Soil Su -Remolded Soil Su }} \times 100 \%$

Where:-

Intact soil $\mathrm{Su}=$ the undrained shear strength of the undisturbed soil $=15.26 \mathrm{kPa}$.

Remolded soil $\mathrm{Su}=$ the undrained shear strength of the remolded soil $=8.175 \mathrm{kPa}$.

Week (i) $=$ week No (i) after reconstituting soil.

From Table 4, it can be noticed that the percent of strength degradation upon soil remolding is about $45 \%$ measured immediately after remolding and reconstituting the soil specimens. This degradation is attributed to the destruction of the bonds between soil particles and rearranging these particles in a weaker skeleton during the reconstituting process. With time, the lost strength is gradually regained as shown in the last column of Table 4. The percent of strength regaining reaches about $100 \%$ after 25 weeks.

Fig. 2 below displays the trend of variation of the undrained shear strength with time. The solid line in this figure represents the best fit curve for all the tests results that are represented as discrete filled points. It is obvious that the rate of strength regaining is relatively high during the first three weeks. This rate gradually decreases for the following time period. More than $60 \%$ of the lost strength is regained during the first five weeks. The strength regaining may be attributed to rearranging and rebuilding of the bonds between soil particles with time.

Table 4. Thixotropy results.

\begin{tabular}{|c|c|c|c|c|c|c|c|c|c|c|c|c|}
\hline \multirow[b]{2}{*}{$\begin{array}{l}\text { Time } \\
\text { in } \\
\text { week }\end{array}$} & \multicolumn{4}{|c|}{ Test 1} & \multicolumn{4}{|c|}{ Test 2} & \multicolumn{4}{|c|}{ Test 3} \\
\hline & $\begin{array}{c}\mathrm{Su} \text { in } \\
\mathrm{kPa}\end{array}$ & $\begin{array}{c}\text { W.C. } \\
\%\end{array}$ & SuR & $\mathrm{SuD}$ & $\begin{array}{c}\text { Su in } \\
\mathrm{kPa}\end{array}$ & $\begin{array}{c}\text { W.C. } \\
\%\end{array}$ & SuR & $\mathrm{SuD}$ & $\begin{array}{c}\mathrm{Su} \text { in } \\
\mathrm{kPa}\end{array}$ & $\begin{array}{c}\text { W.C. } \\
\%\end{array}$ & SuR & $\mathrm{SuD}$ \\
\hline 0 & 8.45 & 34.81 & 3.8 & 44.6 & 8.18 & 35.11 & 0.0 & 46.4 & 8.72 & 35 & 7.7 & 42.9 \\
\hline 0.28 & 8.90 & 36.18 & 10.2 & 41.7 & 8.72 & 34.58 & 7.7 & 42.9 & 8.80 & 34.11 & 8.8 & 42.3 \\
\hline 0.5 & 9.80 & 36.28 & 22.9 & 35.8 & 9.10 & 36.1 & 13.1 & 40.4 & 9.15 & 36.51 & 13.8 & 40.0 \\
\hline 1 & 10.08 & 35.14 & 26.9 & 33.9 & 9.95 & 37.01 & 25.1 & 34.8 & 10.08 & 36.74 & 26.9 & 33.9 \\
\hline 2 & 11.35 & 34.71 & 44.8 & 25.6 & 12.54 & 34.9 & 61.5 & 17.9 & 11.99 & 35.56 & 53.8 & 21.4 \\
\hline 3 & 12.26 & 34.52 & 57.7 & 19.6 & 12.81 & 34 & 65.4 & 16.1 & 12.35 & 34.22 & 58.9 & 19.1 \\
\hline 4 & 13.10 & 34.93 & 69.5 & 14.2 & 13.08 & 35.12 & 69.2 & 14.3 & 13.11 & 35.25 & 69.7 & 14.1 \\
\hline 5 & 12.95 & 36.92 & 67.4 & 15.1 & 13.15 & 33.61 & 70.2 & 13.8 & 13.25 & 33.77 & 71.6 & 13.2 \\
\hline
\end{tabular}




\begin{tabular}{|c|c|c|c|c|c|c|c|c|c|c|c|c|}
\hline 6 & 13.08 & 33.67 & 69.2 & 14.3 & 13.35 & 31.91 & 73.1 & 12.5 & 13.08 & 33.5 & 69.2 & 14.3 \\
\hline 7 & 13.27 & 34.3 & 71.9 & 13.0 & 13.42 & 35.4 & 74.0 & 12.1 & 13.35 & 34.33 & 73.0 & 12.5 \\
\hline 8 & 13.31 & 35.21 & 72.5 & 12.8 & 13.45 & 35.2 & 74.5 & 11.9 & 13.55 & 34.9 & 75.9 & 11.2 \\
\hline 9 & 13.45 & 36.11 & 74.5 & 11.9 & 13.48 & 35.94 & 74.9 & \begin{tabular}{|l|}
11.7 \\
\end{tabular} & 13.65 & 35.2 & 77.3 & 10.6 \\
\hline 10 & 13.60 & 33.78 & 76.6 & 10.9 & 13.35 & 34.43 & 73.1 & 12.5 & 13.90 & 34.22 & 80.8 & 8.9 \\
\hline 11 & 13.93 & 34.46 & 81.2 & 8.7 & 13.85 & 33.59 & 80.1 & 9.2 & 14.01 & 34.7 & 82.4 & 8.2 \\
\hline 12 & 14.11 & 34.4 & 83.8 & 7.5 & 14.05 & 34.19 & 82.9 & 7.9 & 14.17 & 34.3 & 84.6 & 7.1 \\
\hline 13 & 14.32 & 34.42 & 86.7 & 6.2 & 14.12 & 34.33 & 83.9 & 7.5 & 14.19 & 34.21 & 84.9 & 7.0 \\
\hline 14 & 14.41 & 34.03 & 88.0 & 5.6 & 14.45 & 35.2 & 88.6 & 5.3 & 14.25 & 34.91 & 85.7 & 6.6 \\
\hline 15 & 14.50 & 34.55 & 89.3 & 5.0 & 14.52 & 35.55 & 89.6 & 4.8 & 14.44 & 35.84 & 88.5 & 5.4 \\
\hline 16 & 14.99 & 33.43 & 96.2 & 1.8 & 14.41 & 34.12 & 88.0 & 5.6 & 14.47 & 34.25 & 88.8 & 5.2 \\
\hline 17 & 14.99 & 33.76 & 96.2 & 1.8 & 14.44 & 35.61 & 88.5 & 5.4 & 14.51 & 33.59 & 89.4 & 4.9 \\
\hline 18 & 14.72 & 33.95 & 92.3 & 3.6 & 14.50 & 35.29 & 89.3 & 5.0 & 14.78 & 35.8 & 93.2 & 3.1 \\
\hline 19 & 14.72 & 32.44 & 92.3 & 3.6 & 14.65 & 34.27 & 91.4 & 4.0 & 14.99 & 35.2 & 96.2 & 1.8 \\
\hline 20 & 14.99 & 32.38 & 96.2 & 1.8 & 14.72 & 33.56 & 92.3 & 3.6 & 14.86 & 35.7 & 94.4 & 2.6 \\
\hline 21 & 15.03 & 33.5 & 96.8 & 1.5 & 15.15 & 31.59 & 98.4 & 0.7 & 14.94 & 35.85 & 95.5 & 2.1 \\
\hline 22 & 15.10 & 33.64 & 97.7 & 1.0 & 15.26 & 34.51 & 100.0 & 0.0 & 15.15 & 34.2 & 98.4 & 0.7 \\
\hline 23 & 15.35 & 34.31 & 101.3 & -0.6 & 15.31 & 35.22 & 100.7 & -0.3 & 15.26 & 35.93 & 100.0 & 0.0 \\
\hline 24 & 15.41 & 33.97 & 102.1 & -1.0 & 15.55 & 33.13 & 104.1 & -1.9 & 15.25 & 34.37 & 99.9 & 0.1 \\
\hline 25 & 15.35 & 33.9 & 101.3 & -0.6 & 15.26 & 33.55 & 100.0 & 0.0 & 15.36 & 34.02 & 101.4 & -0.7 \\
\hline 26 & 15.19 & 34.44 & 99.0 & 0.5 & 15.15 & 35 & 98.4 & 0.7 & 15.53 & 34 & 103.8 & -1.8 \\
\hline 27 & 15.21 & 34.52 & 99.3 & 0.3 & 15.42 & 35.46 & 102.3 & -1.0 & 15.17 & 33.01 & 98.7 & 0.6 \\
\hline 28 & 15.20 & 34.11 & 99.2 & 0.4 & 15.51 & 33.52 & 103.5 & -1.6 & 15.23 & 34.53 & 99.6 & 0.2 \\
\hline 29 & 15.50 & 33.01 & 103.4 & -1.6 & 15.26 & 33.91 & 100.0 & 0.0 & 15.14 & 34.59 & 98.3 & 0.8 \\
\hline 30 & 15.40 & 33.89 & 102.0 & -0.9 & 15.30 & 35.13 & 100.6 & -0.3 & 15.53 & 35.22 & 103.8 & -1.8 \\
\hline 31 & 15.55 & 34.58 & 104.1 & -1.9 & 15.25 & 32.95 & 99.9 & 0.1 & 15.13 & 35.01 & 98.2 & 0.9 \\
\hline 32 & 15.29 & 34.95 & 100.4 & -0.2 & 15.31 & 33.71 & 100.7 & -0.3 & 15.46 & 35.72 & 102.8 & -1.3 \\
\hline 33 & 15.40 & 35.27 & 102.0 & -0.9 & 15.26 & 33.77 & 100.0 & 0.0 & 15.14 & 34.98 & 98.3 & 0.8 \\
\hline 34 & 15.15 & 33.52 & 98.4 & 0.7 & 15.35 & 35.51 & 101.3 & -0.6 & 15.21 & 34.25 & 99.3 & 0.3 \\
\hline 35 & 15.53 & 34.09 & 103.8 & -1.8 & 15.25 & 32.07 & 99.9 & 0.1 & 15.22 & 35.91 & 99.4 & 0.3 \\
\hline 36 & 15.26 & 32.28 & 100.0 & 0.0 & 15.27 & 33.86 & 100.1 & -0.1 & 15.17 & 35.77 & 98.7 & 0.6 \\
\hline
\end{tabular}




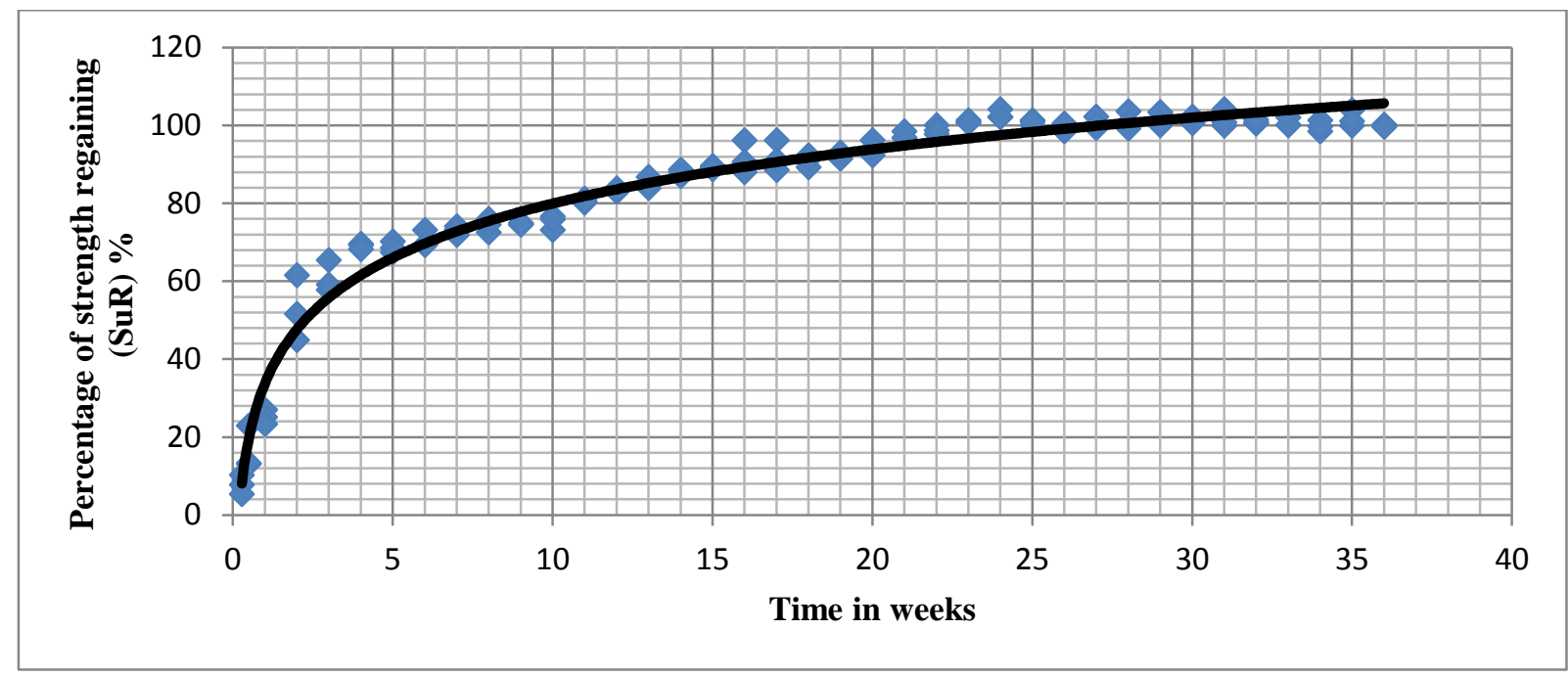

Figure 2. Percentage of strength regaining due to thixotropic effect with time passing in weeks.

As an attempt to obtain a mathematical relation between the strength regaining percent and the time (in days), Fig. 3 below is presented. The elapsed time after soil remolding in this figure is expressed in a logarithmic scale. The best fitting line is almost linear and mathematically can be expressed as:

$\operatorname{SuR}=19.852 \ln (\mathrm{t})-4.223$

where $t$ is the time in days ranging from (2-252).

$\mathrm{R}^{2}=0.97$ and the No. of points is 114 point.

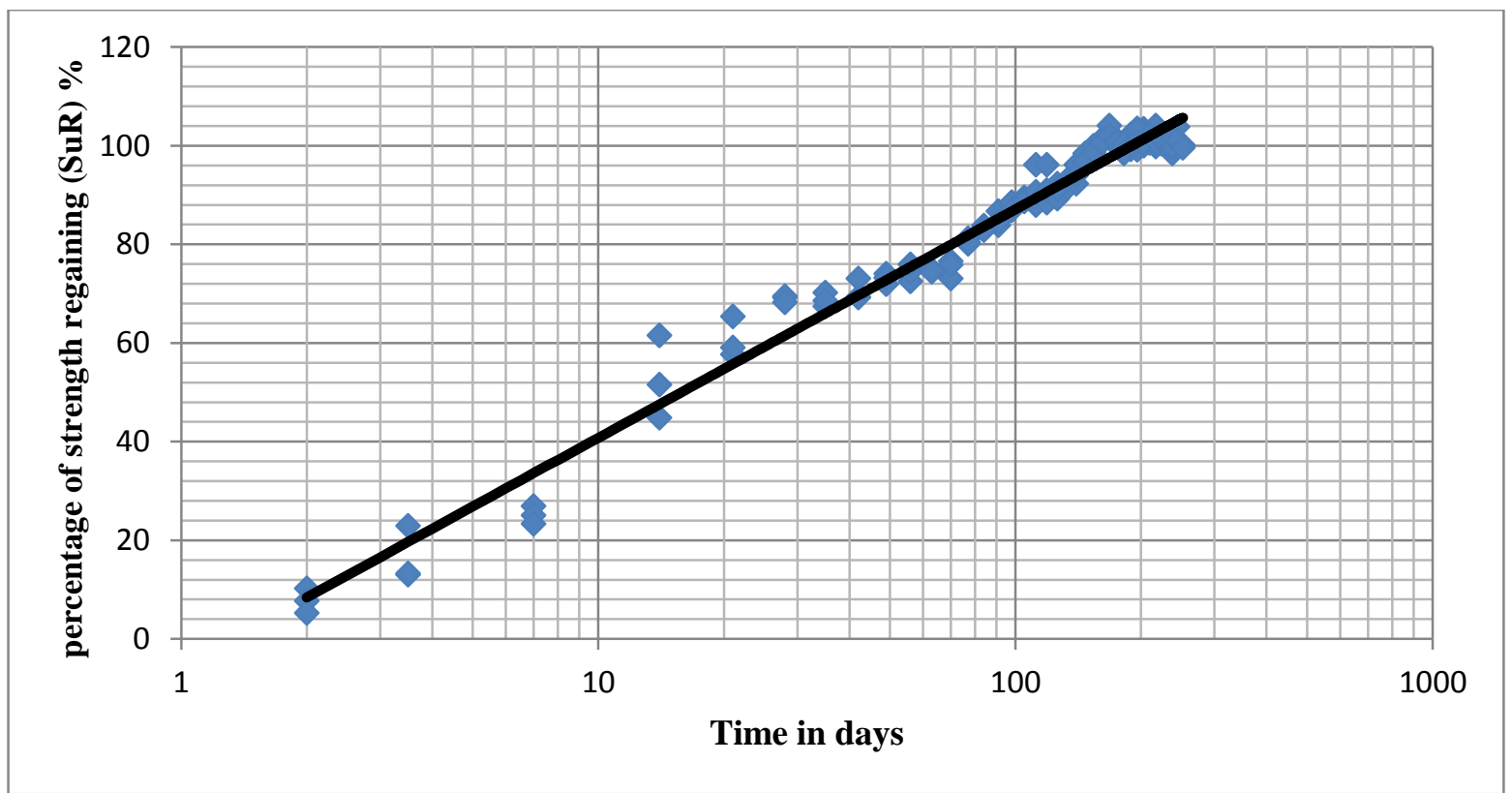

Figure 3. Percentage of strength regaining due to thixotropic effect with time passing in days using a logarithmic scale. 


\section{CONCLUSIONS}

In this study, the thixotropic effects of the Fao clay were investigated throughout a time period of about 36 weeks. The undrained shear strength of the intact soil was measured first then that of thoroughly remolded is obtained after reconstituting the natural soil. The following points can be deduced as concluding remarks:

1. The shear strength of the undisturbed Fao clay is almost twice as the shear strength of the remolded Fao clay.

2. The direct shear test can be adopted to measure the undrained shear strength of clayey soil provided that the shearing rate is so rapid that ultimate strength can be reached within a time period less than one-eighth of time required to reach $50 \%$ consolidation.

3. The strength regaining percent increases with the elapsed time after remolding. About $100 \%$ of strength regaining can be reached within 25 weeks.

4. A mathematical expression that relates the strength regaining percent to the elapsed time in days is presented and could be helpful for practical purposes relevant to the Fao region.

\section{REFERENCES}

- Al-Mufty A.A, 1990, Analysis of Stress Deformation Behavior of Fao soil, MSc thesis, College of Engineering, University of Baghdad, Iraq.

- Bro, A. D., Stewart, J. P., and Pradel, D., 2013, Estimating undrained strength of clays from direct shear testing at fast displacement rates. In Geo-Congress 2013: Stability and Performance of Slopes and Embankments III, PP. 106-119.

- Chan, C. M., and Yong, H. Y., 2014, Comparing the Thixotropic and Lightly Solidified Hardening Behavior of a Dredged Marine Clay. Engineering, Technology and Applied Science Research, Vol. 4, No. 5, PP. 706-710.

- Farsakh, M.A., Rosti, F. and Souri, A., 2015, Evaluating pile installation and subsequent thixotropic and consolidation effects on setup by numerical simulation for full-scale pile load test, Can. Geotech. J. Vol. 52, No. 11, PP. 1734-1746.

- Freundlich, H., 1935, Thixotropy, Hermann, Paris.

- Khaldoun, A., Moller, P., Fall, A., Wegdam, G., De Leeuw, B., Méheust, Y., and Bonn, D., 2009, Quick clay and landslides of clayey soils, Physical review letters, Vol.103, No. 18, PP. 188-301.

- Mathes, J. A., 1968, Thixotropic effects in a clay-water system, Masters Theses.

- Mitchell, J. K., 1961, Fundamental aspects of thixotropy in soils, Transactions of the American Society of Civil Engineers, Vol. 126, No. 1, PP. 1586-1620.

- Peterfi, T., 1927, The separation of the fertilization membrane of sea urchin eggs, Arch. Entwicklungsmech, Organ, Vol. 112, PP. 660-695.

- Shahriar, A. R., Abedin, M. Z., and Jadid, R., 2018, Thixotropic aging and its effect on 1-D compression behavior of soft reconstituted clays, Applied Clay Science, Vol.153, PP. 217-227.

- Skempton, A.W., Northey, R.D., 1952. The sensitivity of clays. Geotechnique, Vol. 3, No. 1, PP. 30-53.

- Solonenko, V.P., 1977, Landslides and collapses in seismic zones and their prediction. Bull, Eng. Geol. Environ. Vol. 15, No. 1, PP. 4-8. 
- Standard, A. S. T. M., D4318-10, 2010, Standard Test Methods for Liquid Limit, Plastic Limit, and Plasticity Index of Soils., ASTM International, West Conshohocken, Pa, USA.

- Standard, A. S. T. M. D2216-10, 2010, Standard test methods for laboratory determination of water (moisture) content of soil and rock by mass, ASTM International, West Conshohocken, Pa, USA.

- Standard, A. S. T. M. D7263-09, 2014, Standard Test Methods for Laboratory Determination of Density (Unit Weight) of Soil Specimens, ASTM International, West Conshohocken, Pa, USA.

- Standard, A. S. T. M., D2487 -17, 2017, Standard Practice for Classification of Soils for Engineering Purposes (Unified Soil Classification System), ASTM International, West Conshohocken, Pa, USA.

- Standard, A. S. T. M., D3080/D3080M-11, 2011, Standard test method for direct shear test of soils under consolidated drained conditions, ASTM International, West Conshohocken, Pa, USA.

- Standard, A. S. T. M., D6913-04, 2004, Standard test methods for particle size distribution of soils using Sieve Analysis, ASTM International, West Conshohocken, Pa, USA.

- Standard, A. S. T. M., D7928-17, 2017, Standard Test Method for Particle-Size Distribution (Gradation) of Fine-Grained Soils Using the Sedimentation (Hydrometer) Analysis, ASTM International, West Conshohocken, Pa, USA.

- Standard, A. S. T. M., D854-10, 2010, Standard test methods for Specific gravity of soil solids by water pycnometer, ASTM International, West Conshohocken, Pa, USA.

- Zhang, X. W., Kong, L. W., Yang, A. W., and Sayem, H. M., 2017, Thixotropic mechanism of clay: A microstructural investigation, Soils and Foundations, Vol. 57, No. 1, PP. 23-35.

\section{NOMENCLATURE}

\begin{tabular}{|c|c|}
\hline ASTM & $=$ american society for testing and materials. \\
\hline T.S.S & $=$ total soluble salts. \\
\hline $\mathrm{SuD} \%$ & $\begin{array}{l}=\text { percent of undrained shear strength degradation due to the } \\
\text { remolding of soil compared to that of intact soil. }\end{array}$ \\
\hline $\mathrm{SuR} \%$ & $\begin{array}{l}=\text { percent of strength regaining due to thixotropic effect compared to } \\
\text { the lost amount of strength upon remolding. }\end{array}$ \\
\hline $\mathrm{Su}$ & $=$ undrained shear strength. \\
\hline W.C. $\%$ & $=$ water content. \\
\hline
\end{tabular}

